\title{
Research
}

\section{Quantifying Expected Ecological Response to Natural Resource Legislation: a Case Study of Riparian Buffers, Aquatic Habitat, and Trout Populations}

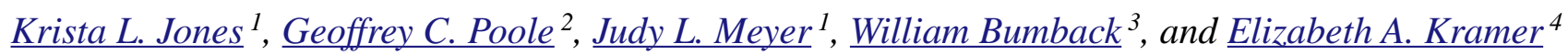

\begin{abstract}
Regulations governing the management of streamside vegetation (riparian buffers) lie at a nexus between environmental, social, and land development interests, and can yield especially contentious debates among stakeholders. In 2001, the State Legislature of Georgia, USA, took up this debate; the Legislature reduced the minimum width of mandatory-forested riparian buffers along designated trout streams from $\sim 30 \mathrm{~m}(100 \mathrm{ft})$ to $\sim 15 \mathrm{~m}(50 \mathrm{ft})$, and commissioned this study to assess the expected response of existing trout populations. Because our research was designed to provide rigorous and accessible data for informing this management debate, this research may serve as a general template for other studies designed to inform regulatory and management decisions. We established and quantified relationships among riparian forests, aquatic habitat (stream temperature and riffle embeddedness), and trout reproductive success (biomass of young trout). We used these relationships to determine the expected impacts of the buffer width reduction on aquatic habitat and trout reproductive success at the stream segment and stream network scales, and assessed associated uncertainty. When compared with stream segments having 30-m wide buffers, our analysis indicated that individual stream segments with 15 -m wide buffers have: 1 ) higher peak temperatures (average peak stream temperatures during the warmest week of the year increase by $\sim 2.0 \pm 0.3^{\circ} \mathrm{C}$, depending on summertime climate conditions); and 2) more fine sediments (fines in riffle habitats increase by approximately $25 \%$ of the observed inter-study-site range). The data show that trout populations will respond markedly to these habitat changes. Linear regression models and an associated Monte Carlo uncertainty assessment document an expected $87 \%$ reduction in young trout biomass, with a $95 \%$ confidence interval ranging from a $66 \%$ reduction to a $97 \%$ reduction. A landscape assessment showed that $63 \%$ of Georgia's $2^{\text {nd }}$ - to $5^{\text {th }}$-order trout stream segments could maintain stream temperatures likely (>50\% probability) to support young trout in streams bordered by $30-\mathrm{m}$ wide forested riparian buffers. Less than $9 \%$ of those streams (only those at the highest elevations) would maintain such temperatures with 15-m wide riparian buffers. As young trout are indicative of trout reproductive success, our results portend substantial reductions or elimination of trout populations in northern Georgia streams where vegetated riparian buffer widths are reduced to $15 \mathrm{~m}$.
\end{abstract}

Key Words: Georgia; natural resource legislation; riparian buffer width; scientific assessment; sediment; southern Appalachians; stream temperature; trout

\section{INTRODUCTION}

Forested riparian ecosystems influence physical components of streams, including temperature dynamics, water quality, sediment regimes, foodweb resources, and instream habitat heterogeneity (Barton et al. 1985, Gregory et al. 1991, Davies and Nelson 1994, Correll 1997, Naiman and Decamps 1997, Wallace et. al 1997, Naiman et al. 2000,
Kiffney et al. 2003, Pusey and Arthington 2003). Because of these diverse functions, riparian forests can maintain high-quality instream habitats that are necessary for fishes with specialized habitat requirements (Barton et al. 1985, Theurer et al. 1985, Salo and Cundy 1987, Marcus et al. 1990, Jones et al. 1999). Strips of undisturbed streamside vegetation (riparian buffers) lessen the impacts of land-use activities on aquatic ecosystems and fauna.

\footnotetext{
${ }^{1}$ Institute of Ecology, University of Georgia, ${ }^{2}$ Eco-metrics, Inc. and Institute of Ecology, University of Georgia, ${ }^{3}$ River Basin Center, University of Georgia, ${ }^{4}$ Natural Resources Spatial Analysis Laboratory, University of Georgia
} 
Recommendations for widths of riparian buffers range from $<10 \mathrm{~m}$ to $>90 \mathrm{~m}$, and vary based on topography, stream type and size, and presence of fish (FEMAT 1993, Wenger 1999, Lee et al. 2004). These critical riparian areas for natural resource protection also tend to be valuable properties for economic and residential development. Thus, regulations governing the management of riparian buffer widths lie at a nexus between environmental, societal, and land development interests, and can yield especially contentious debates among stakeholders.

Such debates can benefit from assessments that quantify the effects of riparian buffer widths on ecological goods and services provided by aquatic ecosystems. Our research provides an example of such an assessment. In 2001, the State Legislature of Georgia, USA, reduced the minimum width of mandatory-forested riparian buffers along designated trout streams from $\sim 30 \mathrm{~m}(100 \mathrm{ft})$ to $\sim 15 \mathrm{~m}(50 \mathrm{ft})$. Two expected consequences of reducing the buffer width are elevated stream temperatures and increased delivery of fine sediment to streams (Barton and Taylor 1985, Gregory et al. 1991, Waters 1995, Scott et al. 2002, Pusey and Arthington 2003). Both warm water and fine sediment can adversely affect the metabolism, growth, and reproductive success of cold-water fishes, including trout (Hausle and Coble 1976, Crisp 2000, Curry and MacNeill 2004, Suttle et al. 2004). Because of these anticipated changes and the economic value of the recreational trout fishery, we were asked by the State Legislature to quantify the responses of aquatic habitat and existing trout populations to the buffer width reduction and to determine whether $15-\mathrm{m}$ wide buffers are adequate to protect trout populations.

We present our research as a specific assessment of the consequences of narrower forested riparian buffers for aquatic habitat and trout in north Georgia. More broadly, however, it serves as an example of how landscape-level ecological assessments can be derived from simple and easily interpreted conceptual models relating land use to ecosystem goods and services (Fig. 1). We believe our approach makes the research results more accessible to governmental policy makers and regulators and, thus, better able to contribute to political discourse regarding natural resource management.

\section{STUDY LANDSCAPE}

The study landscape is located in the Blue Ridge physiographic province of northeastern Georgia, USA, and spans the terminus of the southern Appalachian Mountains and the Chattahoochee, Coosa, Savannah, and Tennessee river drainages (Fig. 2A-B). The Georgia Department of Natural Resources (DNR) designates the Georgia trout stream network and classifies streams as either "primary" trout streams where reproducing trout populations likely exist or "secondary" trout streams where trout are stocked for a put and take fishery but are not expected to reproduce or maintain viable populations. Georgia's trout streams are subject to water quality standards intended to support a recreational trout fishery (Georgia Environmental Protection Division 2004). The dissolved oxygen standard for all trout streams requires at least $6.0 \mathrm{mg} / \mathrm{L}$ as a daily average and 5.0 $\mathrm{mg} / \mathrm{L}$ for any instantaneous reading. Permitted discharges cannot exceed instream water temperature at the point of discharge for primary streams and more than $\sim 1.1^{\circ} \mathrm{C}\left(2^{\circ} \mathrm{F}\right)$ for secondary streams.

Across the landscape, average widths of existing riparian buffers range from $<15 \mathrm{~m}$ to $>30 \mathrm{~m}$ (Fig. $3 \mathrm{~A})$. In most areas, riparian areas have been preferentially deforested relative to their nearly completely forested basins (Fig. 3A-C; see App. 1 for information on existing forest and thermal conditions across Georgia's trout stream network).

Under a closed forest canopy, streams flow swiftly over bedrock, cobble, and gravel streambeds. Our monitoring data show that the annual maximum of the 7-day average maximum daily temperatures (M7DAM temperature) ranges from $17.5-20.0^{\circ} \mathrm{C}$ among sites with undisturbed upstream riparian zones. Because summertime water temperatures under full canopies approach reported upper thermal limits for all three trout species found in Georgia (Table 1), our study landscape is at the southern terminus of trout habitat in the eastern U.S. (Behnke 2002). 
Fig. 1. Conceptual framework for quantifying the relationships between forested riparian buffers, aquatic habitat, and trout populations in north Georgia. Riparian buffers directly influence stream temperature and riffle embeddedness (or fine sediment accumulation in riffle habitats) and, thereby, indirectly influence trout populations.

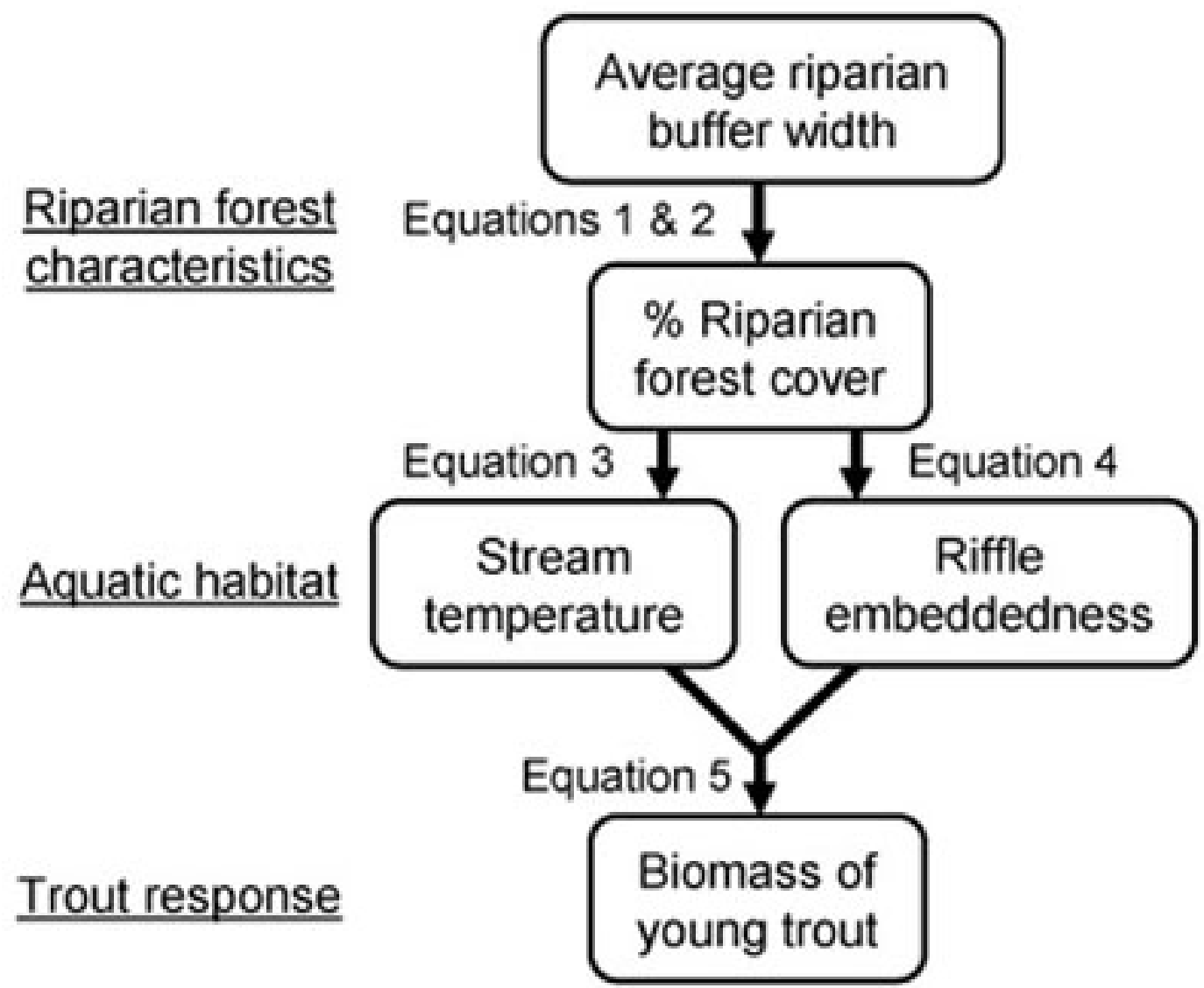

\section{METHODS}

\section{Conceptual Model Development}

We believe scientific information is more apt to be absorbed by the political process if: 1) the research design is transparent so that the overall study design can be easily conveyed to nonscientists; and 2) the end results are expressed in metrics to which politicians and citizens can relate. Thus, we developed our conceptual model based on welldocumented relationships between riparian forests, aquatic habitat, and trout (Fig. 1). This conceptual "road map" makes the research design more apparent, and facilitates communication with non- scientific audiences. Quantifying expected population response (rather than just the magnitude of habitat change) was also important because citizens and politicians are far more likely to understand the implications of changes in trout populations than the implications of changes in habitat.

\section{Trout Stream GIS Database}

We developed a geographic information system (GIS) database of Georgia's trout stream network for site selection and landscape analyses (Table 2). The stream network is composed of discrete stream segments (lengths of stream between tributaries; 
Fig. 2. Study landscape and sampling sites. A) The Georgia trout stream network as classified by the Georgia Department of Natural Resources with primary and supplemental sampling sites (described in Site Selection text). B) Location map outlining the study landscape in the northeastern corner of Georgia, USA. C) Example of a hypothetical stream network. Points denote $2^{\text {nd }}$ order or larger stream segments. For each segment $2^{\text {nd }}$ order or larger, we delineated: 1) the entire upstream catchment draining to the segment; and 2) the adjacent area, or the area along the stream segment directly draining into that segment. For example, the adjacent areas for each of the seven streams segments are denoted by different colored areas.

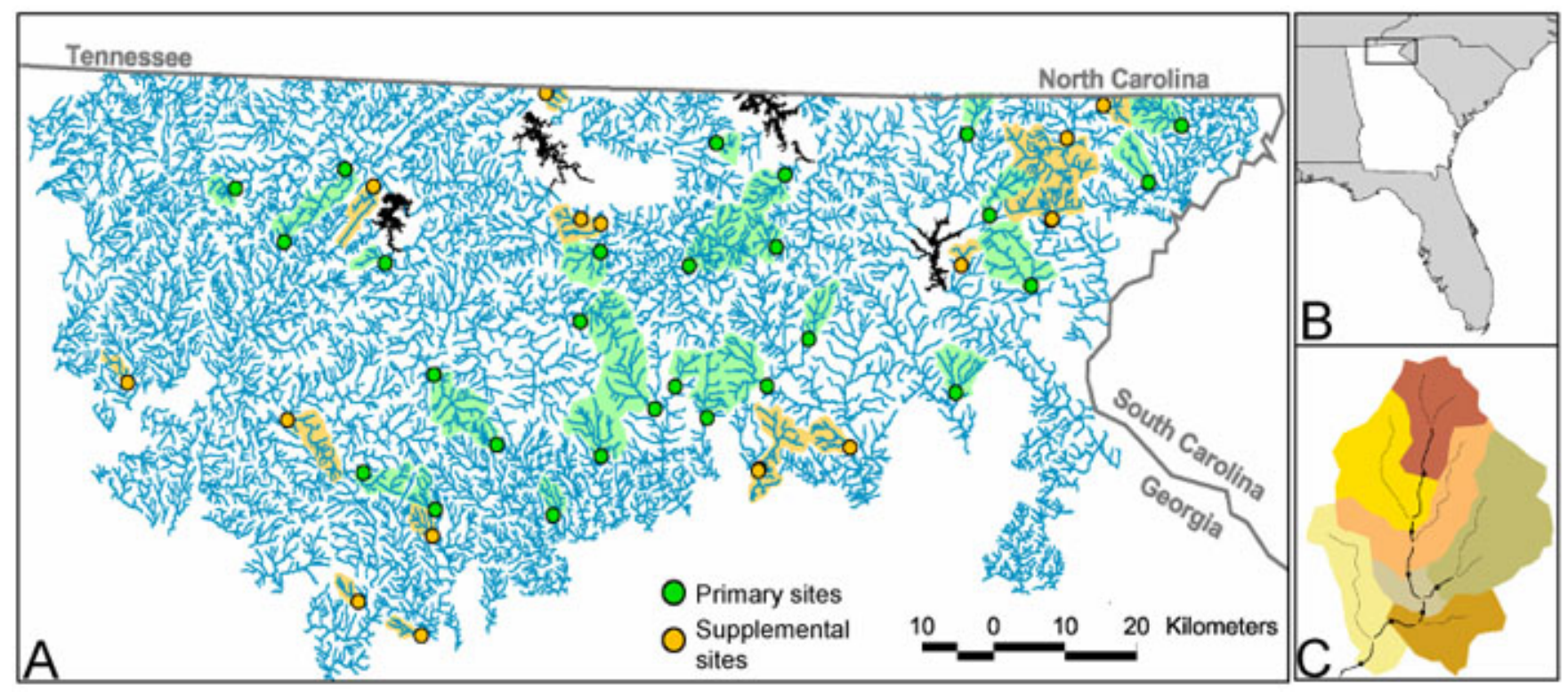

Fig. 2C). The database contains stream order (a measure of position within the network where lower order streams are closer to the headwaters, Strahler 1952) for each of the 8000 trout stream segments based on 1:24 000 U.S. Geological Survey topographic maps. Additionally, for all $2^{\text {nd }}$ order or greater segments in the study landscape, we determined basin area, elevation (from a 1:24 000 digital elevation model) and percent forest cover (from 1998 Landsat imagery). Percent forest cover was determined for: 1) the riparian buffer (a 30-m riparian buffer for the entire stream network upstream of each segment); 2) the catchment of each stream segment (excluding the riparian buffer); and 3 ) the "adjacent area" of each segment (the land area draining directly to the stream segment) (Fig. 2C). Only analyses presented in Fig. 3 and those described in App. 1 used data for the percent forest cover within adjacent areas. The remaining analyses used forest cover within the riparian zone or catchment, as defined above.

Photo interpretation of buffer width for each of the 8000 stream segments would have required thousands of hours and therefore was not feasible. Instead, we developed a relationship to predict average riparian buffer width from riparian forest cover, which can be measured automatically from Landsat data within a GIS. We selected 18 segments from areas where we had color infrared aerial photographs and measured the average forested riparian buffer width within a 30-m zone along the entire network upstream of each segment. We then related percent riparian forest cover and these measured buffer widths with a linear regression. 
Fig. 3. Existing riparian and basin forest conditions across the trout stream network and by land ownership. A) Average forested riparian buffer widths were estimated for more than 8000 stream segments using Eq. 1 from this study. B) Percent forest cover in the adjacent basins (defined in Fig. 2C) for $2^{\text {nd }}$ - to $5^{\text {th }}$-order stream segments with basin areas between 5-50 $\mathrm{km}^{2}$. C) Forest cover in riparian buffers relative to adjacent basin areas for $2^{\text {nd }}$ - to $5^{\text {th }}$-order stream segments with basin areas between 5 $50 \mathrm{~km}^{2}$. Streams without dots have riparian and basin cover values $<90 \%$. Red riparian zones are less forested than adjacent basin areas. For more information on the analysis of existing forest and thermal conditions across Georgia's trout stream network in relation to land ownership, see App. 1.

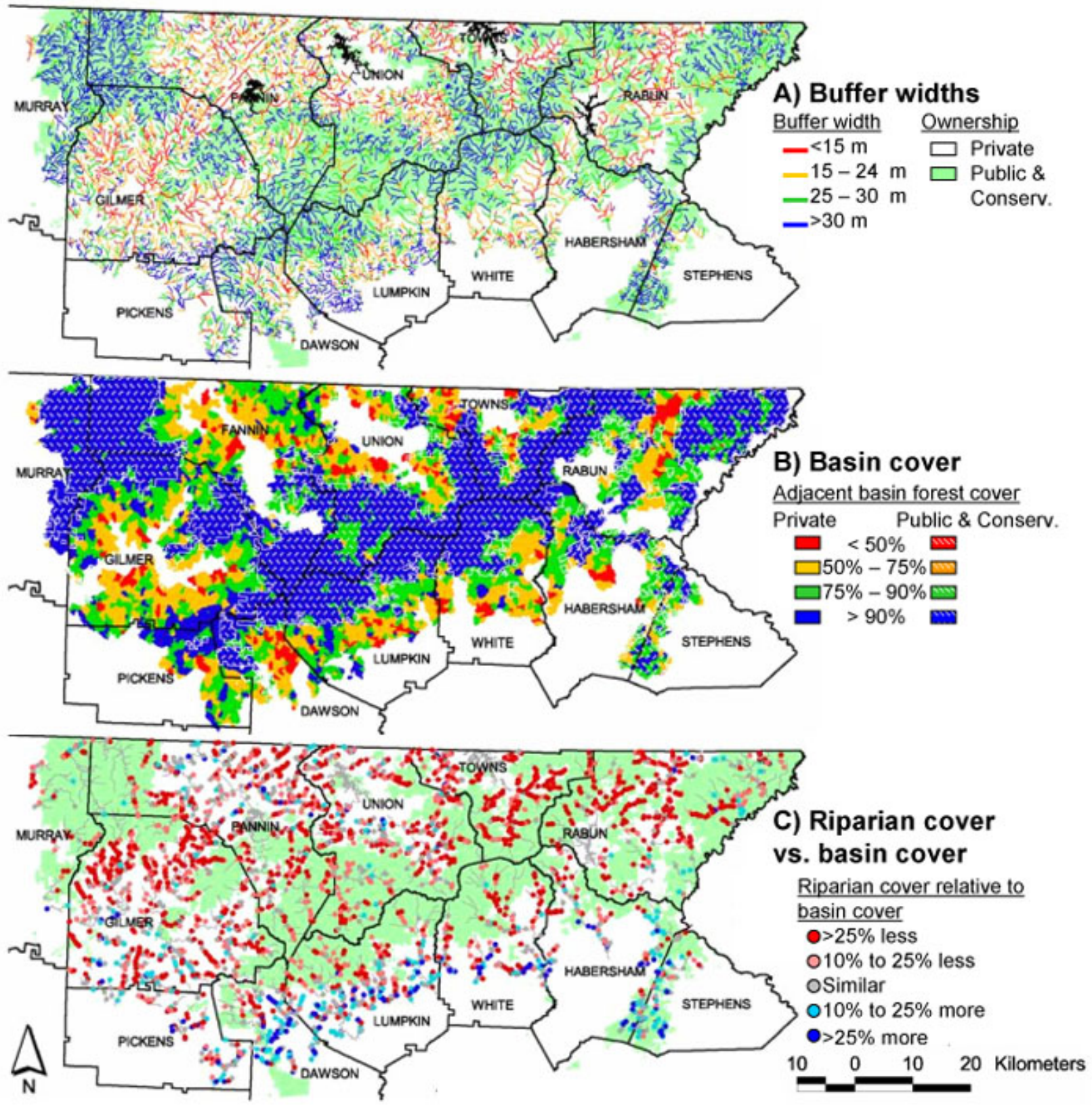


Table 1. Thermal tolerances for trout species found in Georgia. Stocking of rainbow and brown trout has resulted in the establishment of reproducing populations.

\begin{tabular}{llll}
\hline \hline Species & Origin & Upper thermal limit (a) & Source \\
\hline $\begin{array}{l}\text { Oncorhyncus mykiss } \\
\text { (Rainbow trout) }\end{array}$ & Introduced & $\sim 21^{\circ} \mathrm{C}$ & Scott and Crossman (1973) \\
$\begin{array}{l}\text { Salmo trutta } \\
\text { (Brown trout) }\end{array}$ & Introduced & $\sim 24^{\circ} \mathrm{C}$ & Scott and Crossman (1973) \\
$\begin{array}{l}\text { Salvelinus fontinalis } \\
\text { (Brook trout) }\end{array}$ & Native & $\sim 20^{\circ} \mathrm{C}$ & Power (1980)
\end{tabular}

(a) Thermal limits for different life stages (spawning, rearing, migration, etc.) and physiologic characteristics (swimming speed, gamete production, disease resistance, etc.) of each species may vary from the values listed above (e.g., Richter and Kolmes 2005).

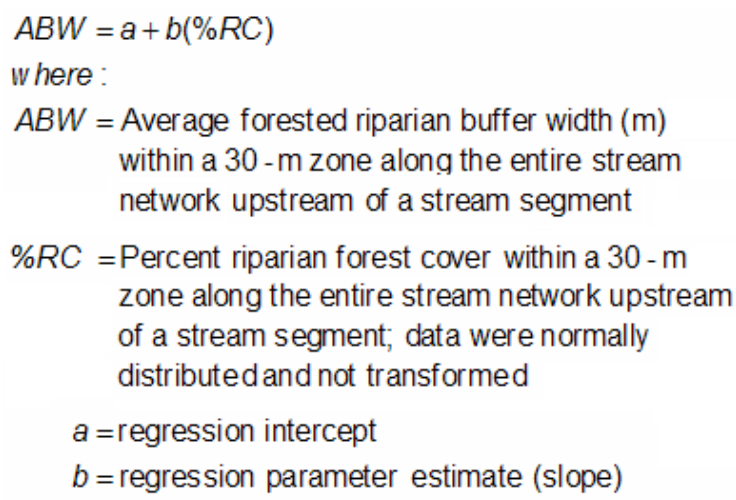

Although other studies have concluded that Landsat data is not adequate to determine local riparian buffer widths for short lengths of stream (e.g., Goetz et al. 2003), analyzing more stream length rectifies this problem. Landsat-derived percent riparian cover was strongly correlated with average forested buffer width if both variables were measured across the entire stream network above any segment (Fig. 4). With Eq. 1, we used Landsat data to estimate average riparian buffer widths for the entire trout stream network (Fig. 3A).

Using the same data but with the independent and dependent variables reversed, the converse equation for calculating percent riparian forest cover values that approximate 30 - and 15-m wide riparian buffers can be derived:

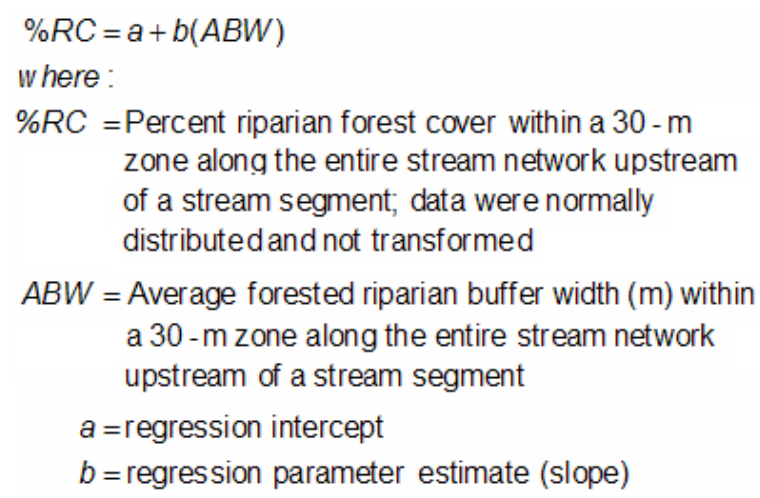

Equation 2 was used in the stream segment scale analysis and Monte Carlo uncertainty assessment, described below.

\section{Site Selection}

To investigate relationships between riparian forests, aquatic habitat, and trout at the stream segment scale, we identified a pool of potential sampling sites $(n=4019)$, which were: a) $2^{\text {nd }}$ order or greater; b) $>1 \mathrm{~km}$ in length; and c) encompassed by catchments between 5 and $50 \mathrm{~km}^{2}$. We chose two groups of sampling sites from this pool. Our primary sites were selected to represent the range of 
Table 2. Base data layers included in the Trout Stream GIS database.

\begin{tabular}{lll}
\hline \hline Data type & Source & Purpose \\
\hline $\begin{array}{ll}\text { 30-m Digital elevation model } \\
\text { (DEM), Georgia }\end{array}$ & US Geological Survey & $\begin{array}{l}\text { Used to determine elevation and basin } \\
\text { area of stream segments }\end{array}$ \\
$1: 24000$ hydrography, Georgia & US Geological Survey & $\begin{array}{l}\text { Provided stream locations on the } \\
\text { landscape and used to determine stream } \\
\text { order }\end{array}$
\end{tabular}

1998 Land cover of Georgia (30-m resolution Landsat satellite imagery)

Georgia Conservation Lands and Georgia Department of Natural Resources

Rules and Regulations for Water Quality Control Chapter 391-3-6, revised August 2000
Natural Resource Spatial Analysis Laboratory (NARSAL), Institute of Ecology, University of Georgia

Natural Resource Spatial Analysis Laboratory (NARSAL), Institute of Ecology, University of Georgia

Georgia Environmental Protection Division
Used to determine percent riparian and catchment forest cover conditions

Used to identify trout streams on private vs. public lands

Used with hydrography layer to identify designated trout streams landscape conditions for $3^{\text {rd }}$ order or larger primary trout streams and to maximize independence among landscape variables that may influence stream temperature. We selected these sites $(n=28)$ from a cluster analysis that separated all $3^{\text {rd }}$ order or larger stream segments into 15 groups, or "clusters" (Fig. 5). Clusters represent stream segments with similar basin area, elevation, and riparian forest cover values. We selected one site from each cluster and then selected additional sites from each cluster in proportion to the number of streams in the cluster. Because of this selection process, the primary sites capture the range of basin area, elevation, and riparian forest cover conditions for $3^{\text {rd }}$ and greater order streams (Table 3 ) yet are also representative of conditions across the landscape. Additionally, this approach yielded a suite of study sites with no correlation among variables used in the cluster analysis (Fig. 6).

After year 2 of our study, data analyses revealed a statistical limitation in our primary data set; forest cover within the riparian buffer and catchment were strongly correlated (regression analysis, $p<0.0001$,
Fig. 7). Given this correlation, both riparian cover and catchment cover were plausible explanations for observed patterns in stream temperature. To determine which scale of forest cover was the more important driver, we identified and sampled supplemental sites $(n=17)$ in year 3 . These sites cover similar landscape gradients as primary sites, but lack correlation between percent riparian and catchment forest cover values (regression analysis, $p=0.8$, Table 4, Fig. 7).

We conducted all analyses with the primary data set except for the analysis separating the influences of riparian vs. catchment forest cover on stream temperature, which was done with the supplemental data set.

\section{Field Data Sets}

We deployed Onset Corp. "HOBO" temperature data loggers to monitor stream temperatures at 30min. intervals at primary sites (2001-2003) and at supplemental sites (2003). We calculated the annual 
Fig. 4. Relationship between percent riparian forest cover (derived from Landsat imagery) and average forested riparian buffer widths (derived from interpretation of color infrared aerial photography) $\left(\mathrm{r}^{2}=\right.$ $0.83, n=18, p<0.01$ ).

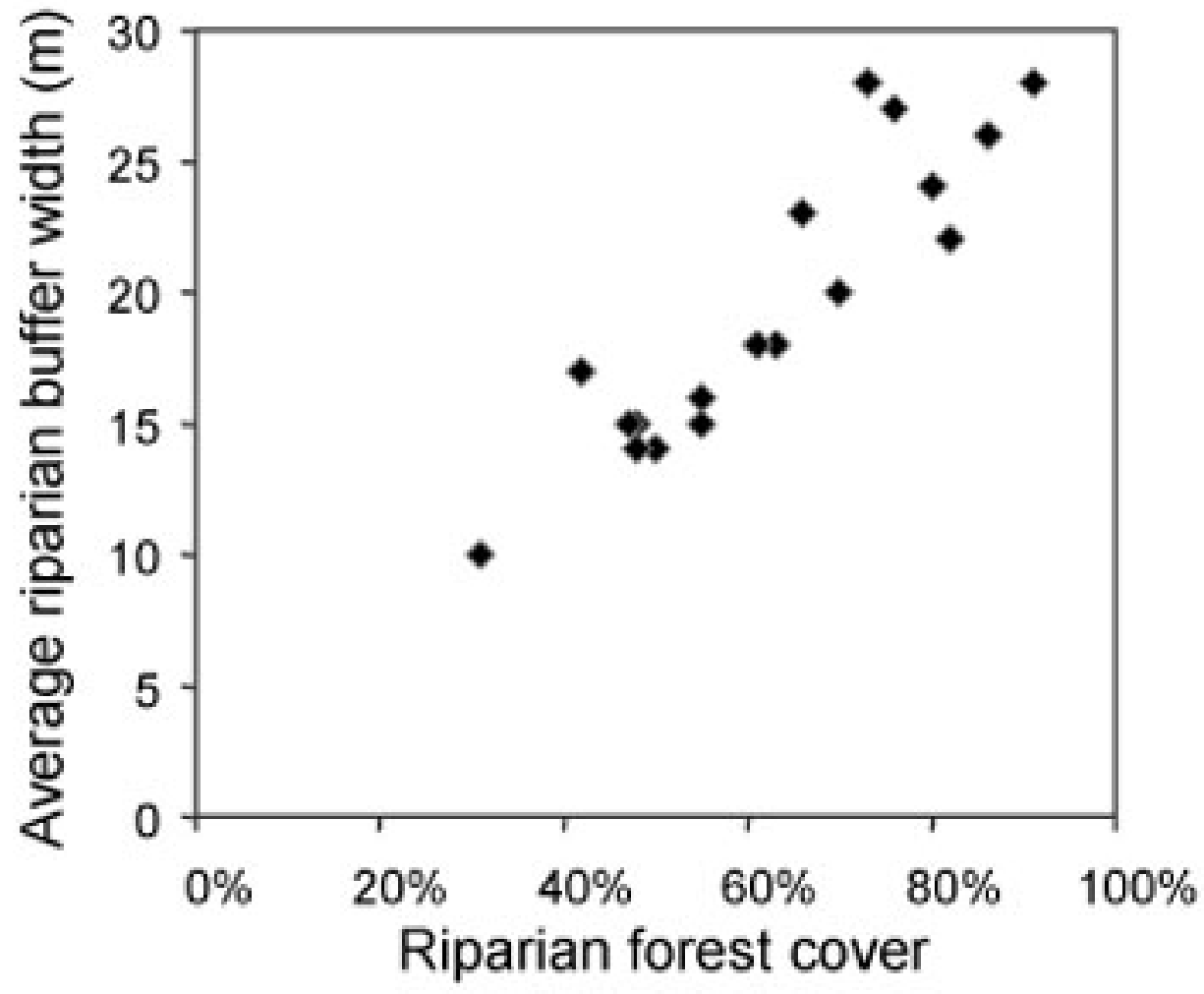

M7DAM temperature for each site and used this value as a quantitative indicator of the peak thermal stress experienced by trout.

At primary sites, we sampled instream habitat and trout biomass according to the schedule shown in Table 3 and collected all measurements from a designated 50-m sampling reach. We measured riffle embeddedness (percentage of sediment particles in riffle habitats surrounded by fine sediments) using methods adapted from Gordon et al. (1992). At each site, the same observer estimated percent riffle embeddedness at ten locations within three riffles using a clear bottom view box. Each of the 30 observations was assigned a class score based on four classes of increasing embeddedness $(1=0$ $25 \%, 2=25-50 \%, 3=50-75 \%$, and $4=75-100 \%$ ).

Summed class scores across each site yield riffle embeddedness index (REI) values for the site. Thus, the range of possible REI values is 30 to 120 , with higher values indicative of higher embeddedness and lower quality habitat for trout. Local stream slope was determined over a 100-m reach of stream, centered on the 50-m sampling site. We measured depth and velocity at 50 points well distributed across the sampling reach to capture variation in these habitat conditions. Velocity was measured using a Marsh-McBirney (Frederick, Maryland) Flo-Mate 2000® flow meter.

Trout populations were sampled throughout the 50$m$ reach in a single pass with a backpack electric shocker, dip nets, and seine net. We only found introduced rainbow and brown trout; generally, native brook trout now occupy only streams smaller than our primary sampling sites. To minimize the 
Fig. 5. Results from the cluster analysis used to select primary sampling sites. The dots represent individual stream segments. Each cluster has similar basin area, elevation, and percent riparian forest cover values.

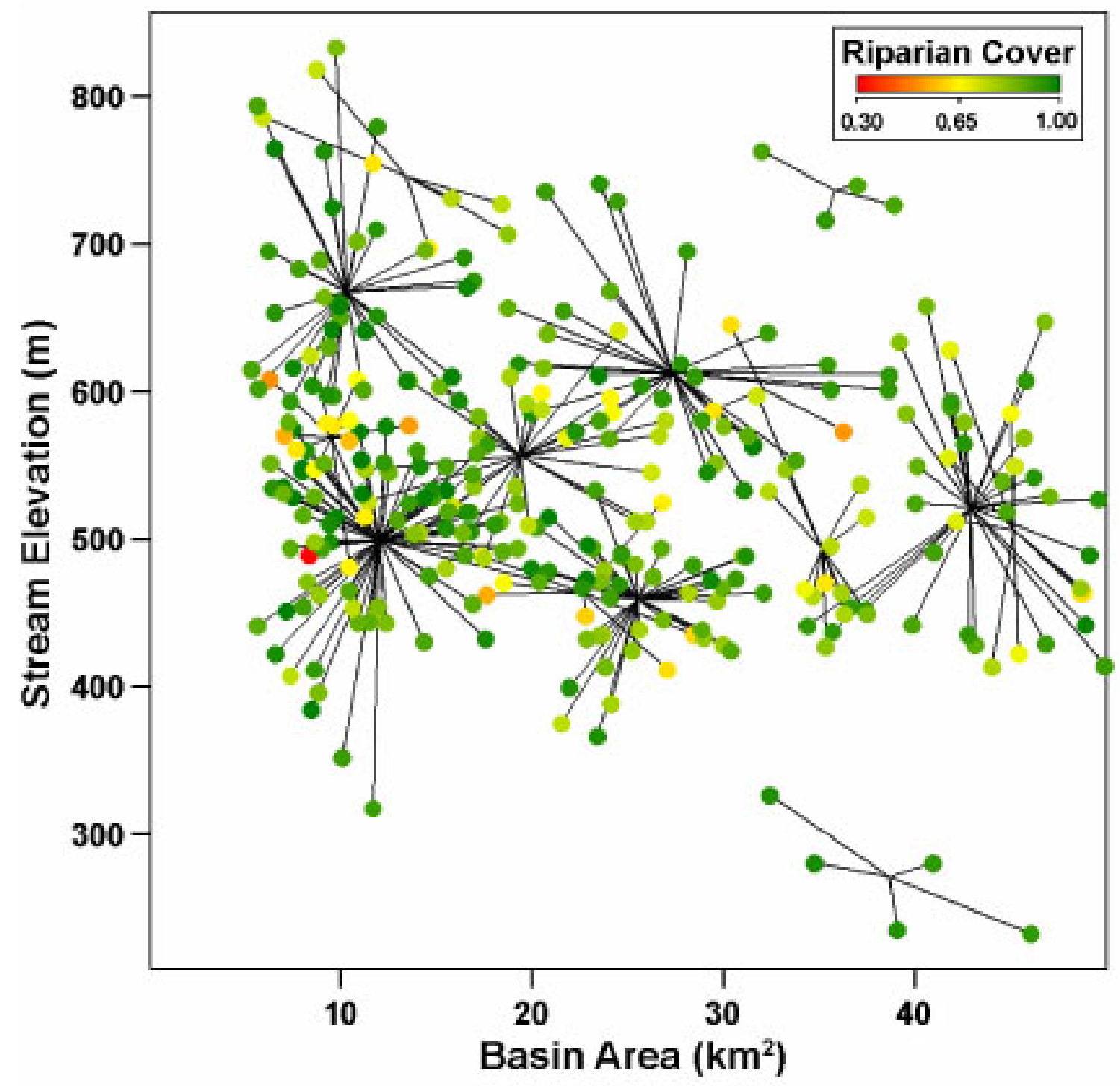


Table 3. Landscape, aquatic habitat, and trout variables measured for primary sampling sites $(n=28)$. In 2002, we resampled velocity and depth conditions and trout at ten sites.

\begin{tabular}{|c|c|c|c|c|}
\hline Variable & Abbreviation & Units & Year & Value range \\
\hline Basin area & BA & $\mathrm{km}^{2}$ & & $6-43$ \\
\hline Elevation & ELEV & $\mathrm{m}$ & & $396-740$ \\
\hline Percent riparian forest cover & $\% \mathrm{RC}$ & $\%$ & 1998 & $29-100$ \\
\hline Percent catchment forest cover & $\% \mathrm{CC}$ & $\%$ & 1998 & 73-99 \\
\hline \multirow[t]{3}{*}{ M7DAM temperature } & \multirow[t]{3}{*}{ M7DAMT } & \multirow[t]{3}{*}{${ }^{\circ} \mathrm{C}$} & 2001 & $17.6-24.5$ \\
\hline & & & 2002 & $18.3-25.1$ \\
\hline & & & 2003 & $16.9-23.5$ \\
\hline Riffle embeddedness index & REI & & 2001 & $31-47$ \\
\hline \multirow[t]{2}{*}{ Maximum reach velocity } & \multirow[t]{2}{*}{ MRV } & \multirow[t]{2}{*}{$\mathrm{m} / \mathrm{sec}$} & 2001 & $0.44-2.2$ \\
\hline & & & 2002 & $0.72-1.48$ \\
\hline \multirow[t]{2}{*}{ Maximum reach depth } & \multirow[t]{2}{*}{ MRD } & \multirow[t]{2}{*}{$\mathrm{m}$} & 2001 & $0.31-1.23$ \\
\hline & & & 2002 & $0.36-0.82$ \\
\hline Local reach slope & LRS & $\%$ over $100 \mathrm{~m}$ & 2001 & $0.2-3.3$ \\
\hline \multirow[t]{2}{*}{ Young trout biomass } & \multirow[t]{2}{*}{ YTB } & \multirow[t]{2}{*}{$\mathrm{g} / 100 \mathrm{~m}^{2}$} & 2001 & $0-76.6$ \\
\hline & & & 2002 & $0-46.2$ \\
\hline
\end{tabular}


Fig. 6. Plots of basin area, elevation, and percent riparian forest cover illustrate the range of conditions across primary sampling sites and independence among these landscape variables.
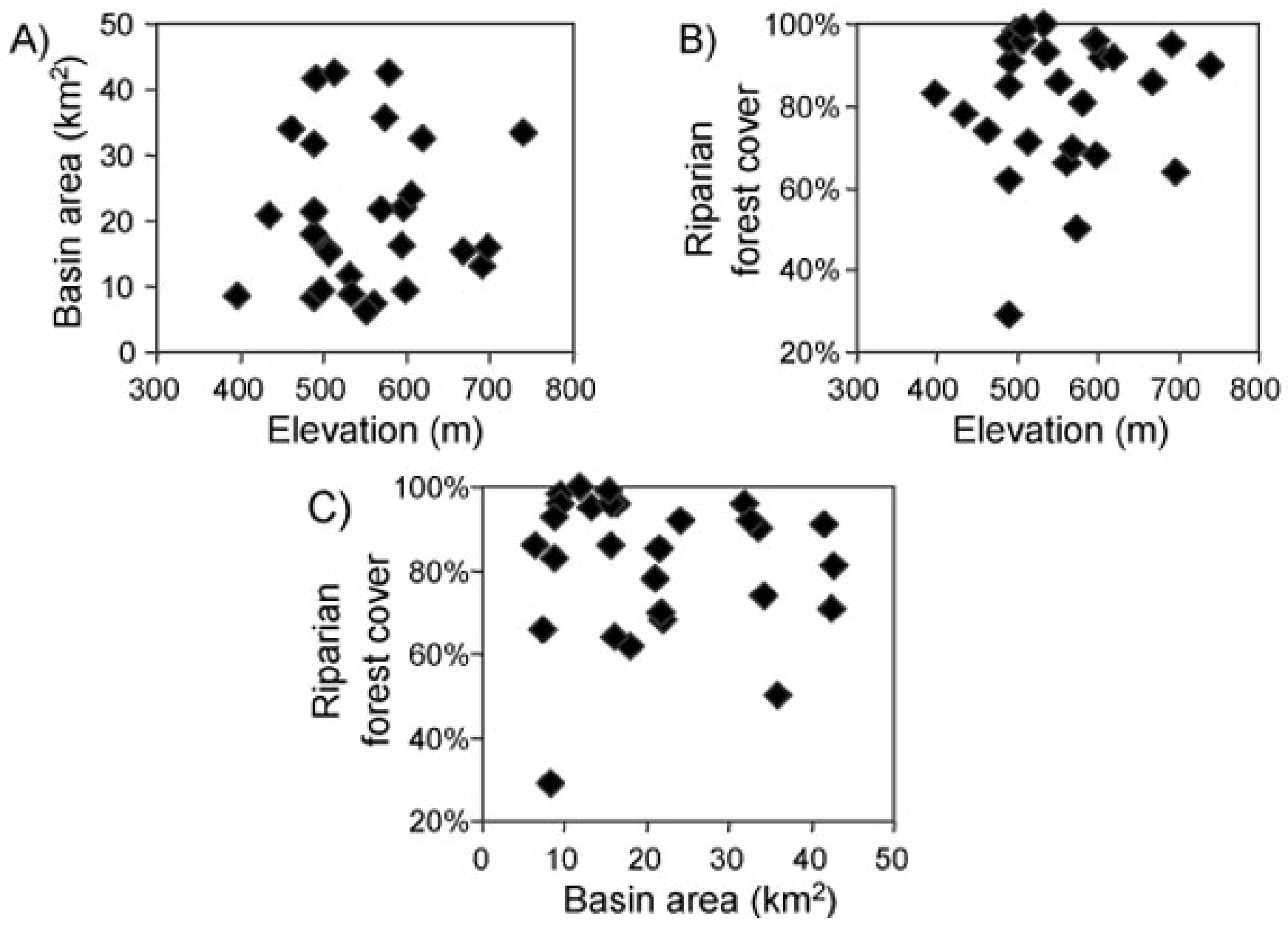

confounding effects of stocking and fishing pressure on trout population size structure, we limited data analyses to naturalized rainbow and brown trout $<150 \mathrm{~mm}$ in total length (henceforth referred to as "young trout"). These young trout are less affected by stocking and fishing because they are smaller than the size stocked in north Georgia and the legal harvestable length. Most importantly, young trout are indicative of successful trout reproduction. We analyzed both the occurrence and biomass of young trout. Biomass was derived from length-weight relationships for young rainbow and brown trout (Schneider et al. 2000, App. 2), summed for each site, and normalized by the sampled surface area of the stream.

\section{Stream Segment Scale Data Analyses}

We applied multiple linear regression techniques $(\alpha$ $=0.05$ ) to quantify the relationships linking riparian forest cover, aquatic habitat, and trout (Fig. 1). Prior to analyses, variables were tested for normality with the Shapiro-Wilk goodness of fit test. In all statistical analyses, biomass of young trout and basin area data were $\log _{10}$ transformed, whereas percent riparian and catchment forest cover values were expressed as fractions between 0 and 1 and then arcsine square root transformed to improve data normality. All final variables for reported regressions were significant and independent of other variables. We conducted all statistical 
Fig. 7. Percent riparian forest cover vs. percent catchment forest cover for the pool of 4019 potential sampling sites (see text). The primary data set (red dots) were $3^{\text {rd }}$ order or larger streams, and are representative of basin area, elevation, and riparian forest cover conditions across the trout stream network (Fig. 5). The supplemental data set (yellow dots) were specifically chosen to have uncorrelated percent riparian and catchment forest cover values $(p=0.8)$.

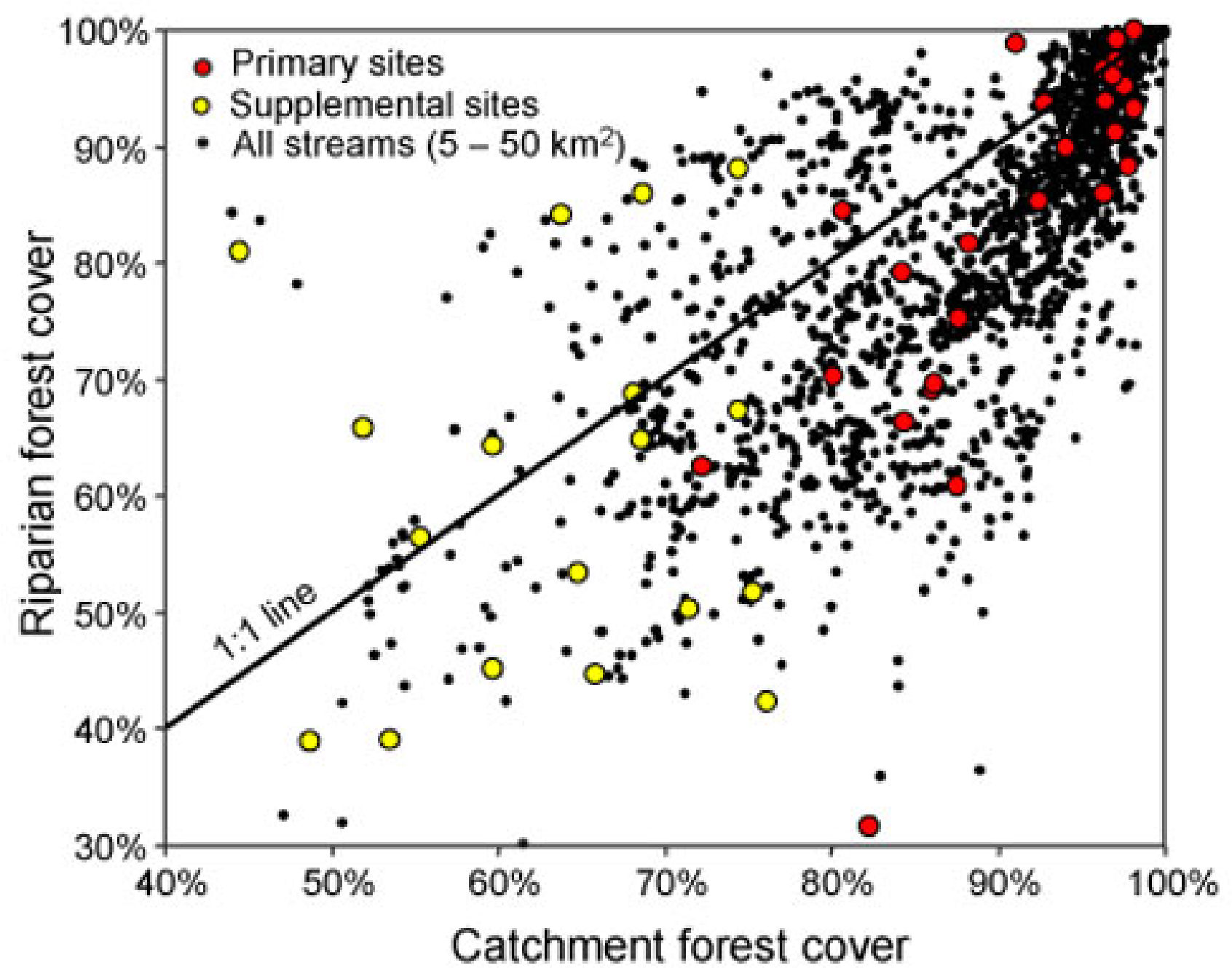


Table 4. Landscape and stream temperature variables measured for supplemental sampling sites $(n=17)$.

\begin{tabular}{lllll}
\hline \hline Variable & Abbreviation & Units & Year & Value range \\
\hline Basin area & BA & $\mathrm{km}^{2}$ & & $5-45$ \\
Elevation & ELEV & $\mathrm{m}$ & & $378-885$ \\
Percent riparian forest cover & $\% \mathrm{RC}$ & $\%$ & 1998 & $39-88$ \\
Percent catchment forest cover & $\% \mathrm{CC}$ & $\%$ & 1998 & $44-76$ \\
& & & & \\
M7DAM temperature & M7DAMT & ${ }^{\circ} \mathrm{C}$ & 2003 & $18.8-23.4$
\end{tabular}

analyses with JMP Version 5 (SAS Institute Inc., Cary, NC, USA).

Based on the findings of Scott et al. (2002), we expected percent riparian forest cover, elevation, and basin area would predict stream temperature. In contrast to Scott et al. (2002), basin area was not a significant predictor of our stream temperature data set. These contrasting results can be explained by the difference in the range of basin areas we sampled $\left(5-50 \mathrm{~km}^{2}\right)$ vs. those sampled by Scott et al. (2002) (5-321 $\mathrm{km}^{2}$ ). Including the arcsine square root transformation to normalize the percent riparian forest cover data, Eq. 3's final form was:

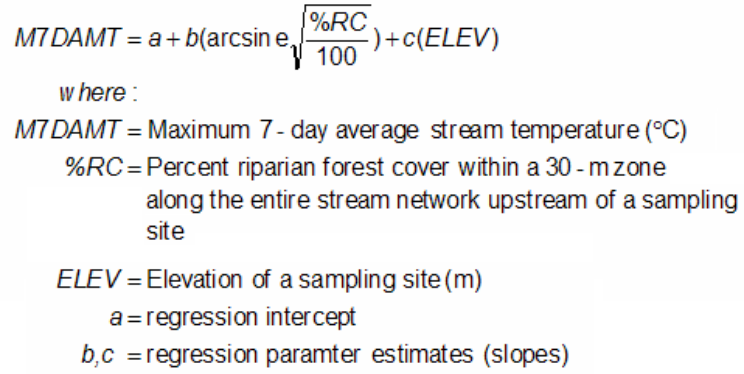

Regression parameter estimates for Eq. 3 were derived individually for the 3 years of data collection at primary sites to account for interannual climate variation.
To determine whether riparian or catchment forest cover drives stream temperature, we used the elevation regression parameter estimate from Eq. 3 to remove the effect of elevation from stream temperature data collected at supplemental sites. We then tested for significant correlations between these elevation-adjusted M7DAM temperatures and both riparian and catchment forest cover data using linear regression.

Reverse step-wise regression techniques were applied to determine Eqs. 4 and 5. Significant predictors of riffle embeddedness (Eq. 4) were identified from the pool of landscape and instream habitat variables (listed in Table 3) with the resulting equation being:

$$
\begin{aligned}
& R E I=a+b\left(\arcsin e \sqrt{\frac{\% R C}{100}}\right)+c(M R V) \\
& \text { where: } \\
& R E I=\text { Riffle embeddedne ssindex value } \\
& \% R C=\text { Percent riparian forest cover within a } 30-\mathrm{m} \\
& M R V=\text { Maximum reach velocity }(\mathrm{m} / \mathrm{sec}) \\
& a=\text { regression intercept } \\
& b, c=\text { regression parameter estimates (slopes) }
\end{aligned}
$$


Table 5. Parameter estimates for Eqs. 1-5, which quantify the relationships between average forested widths of riparian buffers, percent riparian forest cover, instream habitat, and young trout populations in north Georgia. All models and parameter estimates are significant at $\alpha=0.05$. The $95 \%$ confidence interval (C.I.) is calculated as Parameter Estimate $\pm 1.96 \cdot$ S.E. (Sokal and Rohfl 1995).

\begin{tabular}{|c|c|c|c|c|c|c|c|}
\hline $\begin{array}{l}\text { Equation } \\
\text { number }\end{array}$ & $\begin{array}{l}\text { Response } \\
\text { variable }\end{array}$ & Year & $\underset{\mathrm{r}^{2}}{\text { Model }}$ & $\begin{array}{l}\text { Intercepts/ } \\
\text { Predictor variables }\end{array}$ & $\begin{array}{l}\text { Parameter esti- } \\
\text { mate (P.E.) }\end{array}$ & $\begin{array}{l}\text { Standard error } \\
\text { (S.E.) }\end{array}$ & $\begin{array}{l}\text { 95\% Confidence } \\
\text { interval (C.I.) }\end{array}$ \\
\hline \multirow[t]{2}{*}{1} & $\mathrm{ABW}$ & 1998 & 0.83 & Intercept & 0.7438 & 2.2172 & $-3.60-5.09$ \\
\hline & & & & $\% \mathrm{RC}$ & 0.2995 & 0.0344 & $0.23-0.37$ \\
\hline \multirow[t]{2}{*}{2} & $\% \mathrm{RC}$ & 1998 & 0.83 & Intercept & 8.8133 & 6.3828 & $-3.70-21.32$ \\
\hline & & & & $\mathrm{ABW}$ & 2.7582 & 0.3165 & $2.14-3.38$ \\
\hline \multirow[t]{9}{*}{3} & M7DAMT & 2001 & 0.73 & Intercept & 32.9672 & 1.5270 & $29.97-35.96$ \\
\hline & & & & Arcsine $\left[(\% \mathrm{RC} / 100)^{0.5}\right]$ & -4.4827 & 0.8149 & $-6.08--2.89$ \\
\hline & & & & ELEV & -0.0127 & 0.0023 & $-0.02--0.01$ \\
\hline & & 2002 & 0.70 & Intercept & 33.7122 & 1.5923 & $30.59-36.83$ \\
\hline & & & & Arcsine $\left[(\% \mathrm{RC} / 100)^{0.5}\right]$ & -4.7164 & 0.8497 & $-6.38--3.05$ \\
\hline & & & & ELEV & -0.0118 & 0.0024 & $-0.02--0.01$ \\
\hline & & 2003 & 0.57 & Intercept & 29.9048 & 1.8315 & $26.32-33.49$ \\
\hline & & & & Arcsine $\left[(\% \mathrm{RC} / 100)^{0.5}\right]$ & -3.2788 & 0.9855 & $-5.21--1.35$ \\
\hline & & & & ELEV & -0.0110 & 0.0028 & $-0.02--0.01$ \\
\hline \multirow[t]{3}{*}{4} & REI & 2001 & 0.40 & Intercept & 54.3744 & 4.2204 & $46.10-62.65$ \\
\hline & & & & Arcsine $\left[(\% \mathrm{RC} / 100)^{0.5}\right]$ & -8.4651 & 3.1447 & $-14.63--2.30$ \\
\hline & & & & MRV & -5.3289 & 2.2160 & $-9.67--0.99$ \\
\hline \multirow[t]{4}{*}{5} & $\log _{10}(\mathrm{YTB})$ & $\begin{array}{l}2001 \& \\
2002\end{array}$ & 0.72 & Intercept & 10.0440 & 1.5130 & $7.08-13.01$ \\
\hline & & & & M7DAMT & -0.2840 & 0.0480 & $-0.38--0.19$ \\
\hline & & & & REI & -0.0640 & 0.0221 & $-0.11--0.02$ \\
\hline & & & & MRD & -0.0140 & 0.0039 & $-0.02--0.01$ \\
\hline
\end{tabular}


Fig. 8. Logistic model relating the probability of young trout presence to observed M7DAM stream temperatures $\left({ }^{\circ} \mathrm{C}\right)$ for primary sites sampled for trout in 2001 and resampled in $2002(p<0.0001)$.

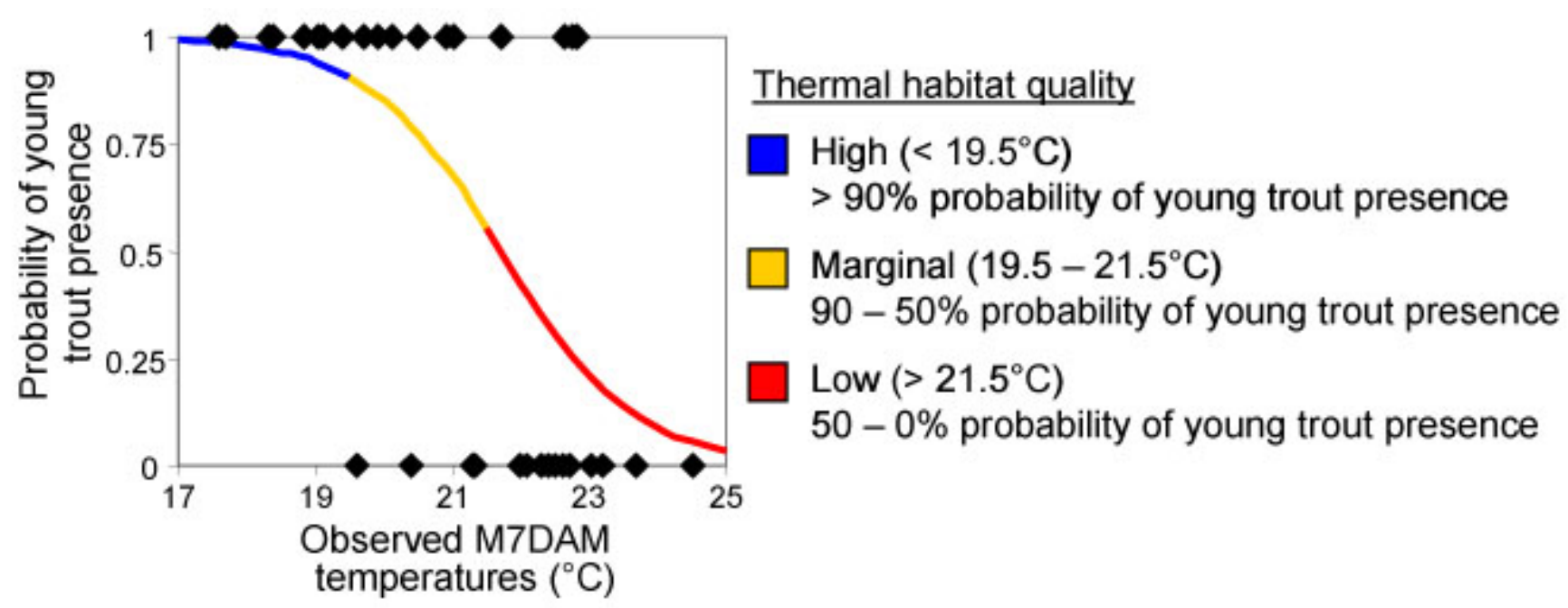

Percent catchment forest cover was not a significant predictor of REI when substituted for \%RC in Eq. 4.

Reverse stepwise regression also identified the significant predictors of young trout biomass (Eq. 5) from the pool of aquatic habitat variables (Table 3 ). Only data from sites with young trout in 2001 and 2002 could be included in this analysis. The final equation was:

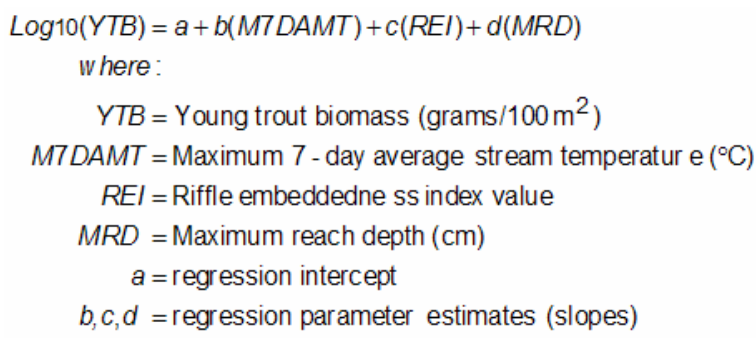

With these equations, we quantified the expected stream temperatures, fine sediment conditions within riffles habitats, and young trout biomass for 30- and 15-m riparian buffer widths.

\section{Model Uncertainty Assessment}

We conducted a Monte Carlo analysis to evaluate the uncertainty associated with young trout biomass responses predicted with Eqs. 2-5. By substituting, respectively, Eq. 2 for \%RC in Eq. 3, and Eqs. 3 and 4 for M7DAMT and REI in Eq. 5, we created a single "master" equation to predict young trout biomass directly from landscape variables. We created $10 \quad 000$ randomized parameter sets (described next) for the master equation and assessed the variation in resulting predictions.

The parameter sets were derived by drawing random values from a normal distribution centered on the regression-derived parameter value, with a standard deviation appropriate for the parameter's standard error, as reported by JMP statistical software. Equation 3 had parameter estimates for each sampling year; the parameters from 2001 were used in the Monte Carlo assessment because, of the 3 years sampled, 2001 air temperatures were most similar to long-term average air temperatures in north Georgia.

Regression intercepts were not randomized because they are fixed for any specific set of slope parameters (Sokal and Rohlf 1995). Intercepts were calculated using: 
Fig. 9. Elevation-adjusted M7DAM temperatures related to percent riparian and catchment forest cover values. A significant relationship was detected between these stream temperatures and percent riparian forest cover $\left(\mathrm{r}^{2}=0.38 ; p=0.01\right)$ but not percent catchment forest cover $(p=0.5)$.
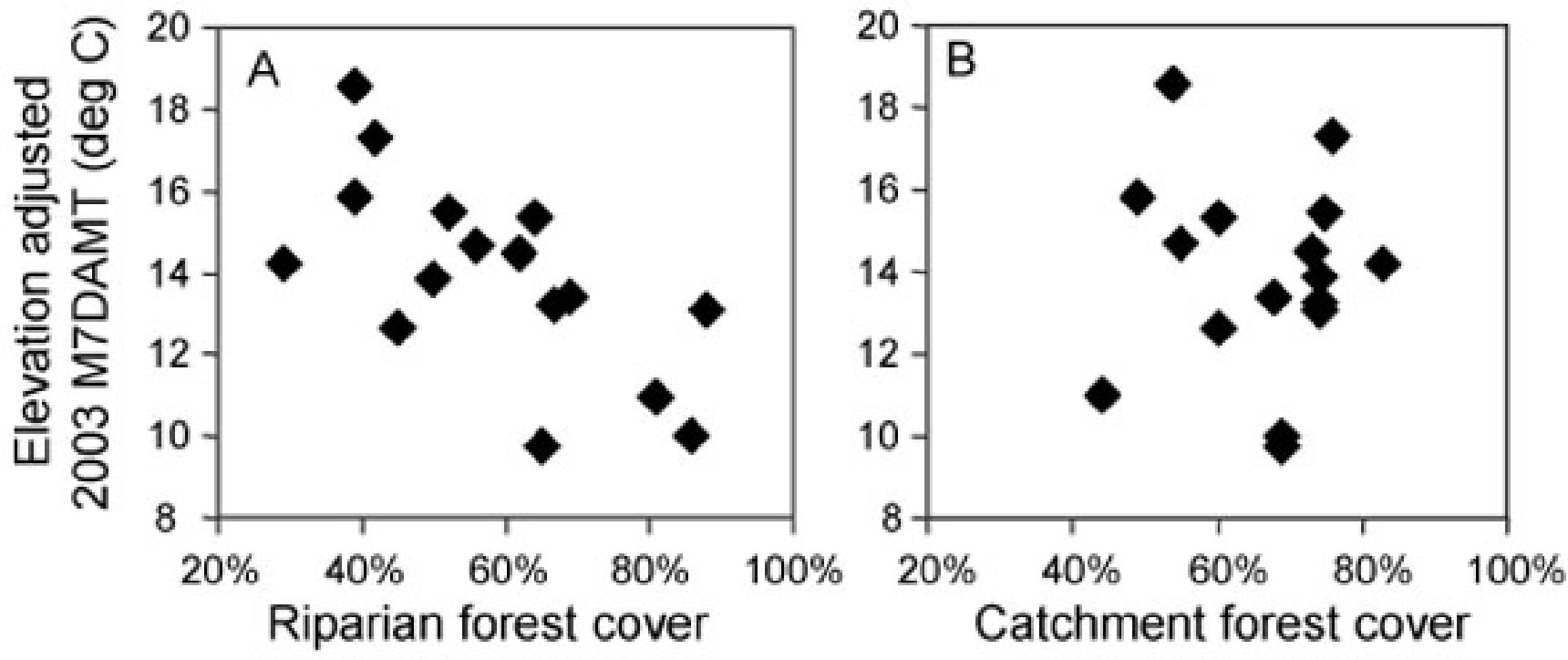

$$
a=\bar{Y}-\sum_{i=1}^{n} b n \bar{X} i
$$

where:

$a=$ Regression intercept

$\bar{Y}=$ Observed mean of response variable

$b n=$ Slope of $n^{\text {th }}$ predictor variable (randomly derived)

$\bar{X}_{i}=$ Observed mean of first predictor variable

$n=$ Number of predictor variables

\section{Stream Network Scale Data Analysis}

Across the stream network, we predicted stream temperatures expected for 30 - and $15-\mathrm{m}$ buffer widths for all $2^{\text {nd }}-5^{\text {th }}$ order trout stream segments using Eqs. 2 and 3 (2001 parameter estimates, Table $5)$. We could not similarly calculate the expected distribution of riffle embeddedness because we lacked measures of stream velocity across the stream network. To link stream network temperatures to trout populations, we identified three categories of trout thermal habitat quality from a logistic regression relating the probability of young trout presence to M7DAM temperatures (Fig. 8 ). The three thermal habitat categories of high $\left(<19.5^{\circ} \mathrm{C}\right)$, marginal $\left(19.5-21.5^{\circ} \mathrm{C}\right)$, and low $\left(>21.5^{\circ} \mathrm{C}\right)$ correspond with a $>90 \%, 50 \%-90 \%$, and $<50 \%$ probability of young trout presence. Using predicted stream temperatures, we mapped out the distribution of these three habitat-quality classes. To provide additional context for governmental policy makers and regulators, we also assessed existing riparian and catchment forest conditions and thermal conditions across the stream network (Fig. 3 and App. 1).

\section{RESULTS}

\section{Local Effects of Network Riparian Cover on Aquatic Habitat and Trout Populations}

M7DAM temperatures from primary sites were consistently and negatively related to percent riparian forest cover and elevation across the three summers (Table 5). Riparian forest cover-not catchment forest cover-was shown to be the significant driver of stream temperature (Fig. 9). 
Table 6. Expected stream temperature (M7DAMT), riffle embeddedness conditions (REI), and young trout biomass (YTB) associated with 30- vs. 15-m average riparian buffer widths along the stream network above a given stream segment. M7DAMT and YTB were calculated for cool, intermediate, and warm summers using the three sets of regression coefficients derived for Eq. 3 and across the elevation range where young trout were observed. REI values were calculated for the range of maximum reach velocities where young trout were observed. YTB was calculated with the average maximum reach depth for sites with young trout $(0.68 \mathrm{~m})$.

\begin{tabular}{|c|c|c|c|c|}
\hline Variable & Gradient(s) & 30-m buffer width & 15-m buffer width & Expected change \\
\hline \multirow[t]{12}{*}{ M7DAMT } & Cool (2003) & & & M7DAMT increase \\
\hline & $488 \mathrm{~m}$ & 20.3 & 21.9 & 1.6 \\
\hline & $578 \mathrm{~m}$ & 19.3 & 20.9 & \\
\hline & $740 \mathrm{~m}$ & 17.5 & 19.1 & \\
\hline & Intermediate (2001) & & & \\
\hline & $488 \mathrm{~m}$ & 21.4 & 23.6 & 2.2 \\
\hline & $578 \mathrm{~m}$ & 20.3 & 22.5 & \\
\hline & $740 \mathrm{~m}$ & 18.4 & 20.6 & \\
\hline & Warm (2002) & & & \\
\hline & $488 \mathrm{~m}$ & 21.9 & 24.2 & 2.3 \\
\hline & $578 \mathrm{~m}$ & 20.9 & 23.3 & \\
\hline & $740 \mathrm{~m}$ & 19.0 & 21.3 & \\
\hline Riffle & Max reach velocity & & & REI increase \\
\hline Embeddedness & 0.04 & 41.4 & 45.6 & $\sim 4.2$ \\
\hline \multirow[t]{4}{*}{ Index (REI) } & 0.8 & 39.3 & 43.4 & \\
\hline & 1.0 & 38.2 & 42.4 & \\
\hline & 1.2 & 37.1 & 41.3 & \\
\hline & 1.6 & 35.0 & 39.2 & \\
\hline Young trout & Cool (2003) & & & $\%$ YTB reduction \\
\hline \multirow[t]{3}{*}{ biomass (YTB) } & $488 \mathrm{~m}$ & 6.62 & 1.26 & 81 \\
\hline & $578 \mathrm{~m}$ & 12.68 & 2.41 & \\
\hline & $740 \mathrm{~m}$ & 40.87 & 7.75 & \\
\hline
\end{tabular}


Intermediate (2001)

$\begin{array}{llll}488 \mathrm{~m} & 4.12 & 0.53 & 87 \\ 578 \mathrm{~m} & 8.70 & 1.12 & \\ 740 \mathrm{~m} & 33.37 & 4.31 & \\ \text { Warm (2002) } & & & 88 \\ 488 \mathrm{~m} & 2.30 & 0.28 & \\ 578 \mathrm{~m} & 4.61 & 0.55 & \\ 740 \mathrm{~m} & 16.07 & 1.92 & \end{array}$

Riffle embeddedness index values increased as percent riparian forest cover decreased (Table 5). The biomass of young trout, indicative of reproductive success, had a negative correlation with M7DAM temperatures and riffle embeddedness index values (Table 5), thus describing the mechanisms by which riparian forest cover influences trout populations.

\section{Local Effects of 30- vs. 15-m Buffer Widths on Aquatic Habitat and Trout Populations}

In stream segments where upstream riparian buffers are reduced from $30 \mathrm{~m}$ to $15 \mathrm{~m}$, the forecasted ecological responses using Eqs. 2-5 are that: 1) M7DAM temperatures will rise by 1.6 to $2.3^{\circ} \mathrm{C}$ depending on interannual climate variation; 2 ) fine sediment in riffle habitats will increase by 4.2 points, or $25 \%$ of the observed inter-study-site range; and 3) biomass of young trout will be reduced by 81 to $88 \%$, depending on stream elevation and interannual climate variation (Table 6).

The effects of statistical uncertainty associated with regression parameters had only a modest effect on the expected $>80 \%$ reduction in young trout biomass (Fig. 10). The expected median reduction in young trout biomass from the Monte Carlo analysis (based on 2001 data) was $87 \%$ with the $95 \%$ confidence interval ranging from $66 \%$ to $97 \%$. The modal (or most likely) reduction in young trout biomass was $88 \%$.

\section{Stream Network Effects of 30- vs. 15-m Buffer Widths on Aquatic Habitat}

Across the trout stream network, 63\% of Georgia's $2^{\text {nd }}-5^{\text {th }}$ order trout stream segments are expected to maintain stream temperatures associated with high and marginal quality thermal habitat (a >50\% chance of supporting young trout) if bordered by a 30-m wide riparian buffer (Table 7, Figs. 8, 11). In contrast, with a $15-\mathrm{m}$ wide riparian buffer, less than 9\% of trout stream segments are expected to maintain the same thermal habitat qualities and these segments are isolated to the highest elevations of the landscape.

\section{DISCUSSION}

\section{Consequences of the Reduction in Riparian Buffer Width for Aquatic Habitat and Self- sustaining Trout Populations}

Relative to 30-m buffer widths, 15-m buffer widths have seemingly modest expected increases in stream temperature $\left(1.6-2.3^{\circ} \mathrm{C}\right)$ and fine sediment in riffles (4.2 index points) (Table 6). Changes of this magnitude, however, appear to degrade habitat sufficiently to preclude reproducing trout populations in most north Georgia streams because trout populations are especially sensitive to changes in temperature and sediment. Only $\sim 2.0^{\circ} \mathrm{C}$ separates streams likely and unlikely to support young trout (Fig. 8). Likewise, a 4.2 point increase in riffle embeddedness is approximately $25 \%$ of the observed range in riffle embeddedness conditions and also the difference between average of riffle 
Fig. 10. Frequency distribution from the Monte Carlo analysis showing the predicted percent reduction in young trout biomass associated with the buffer width reduction.

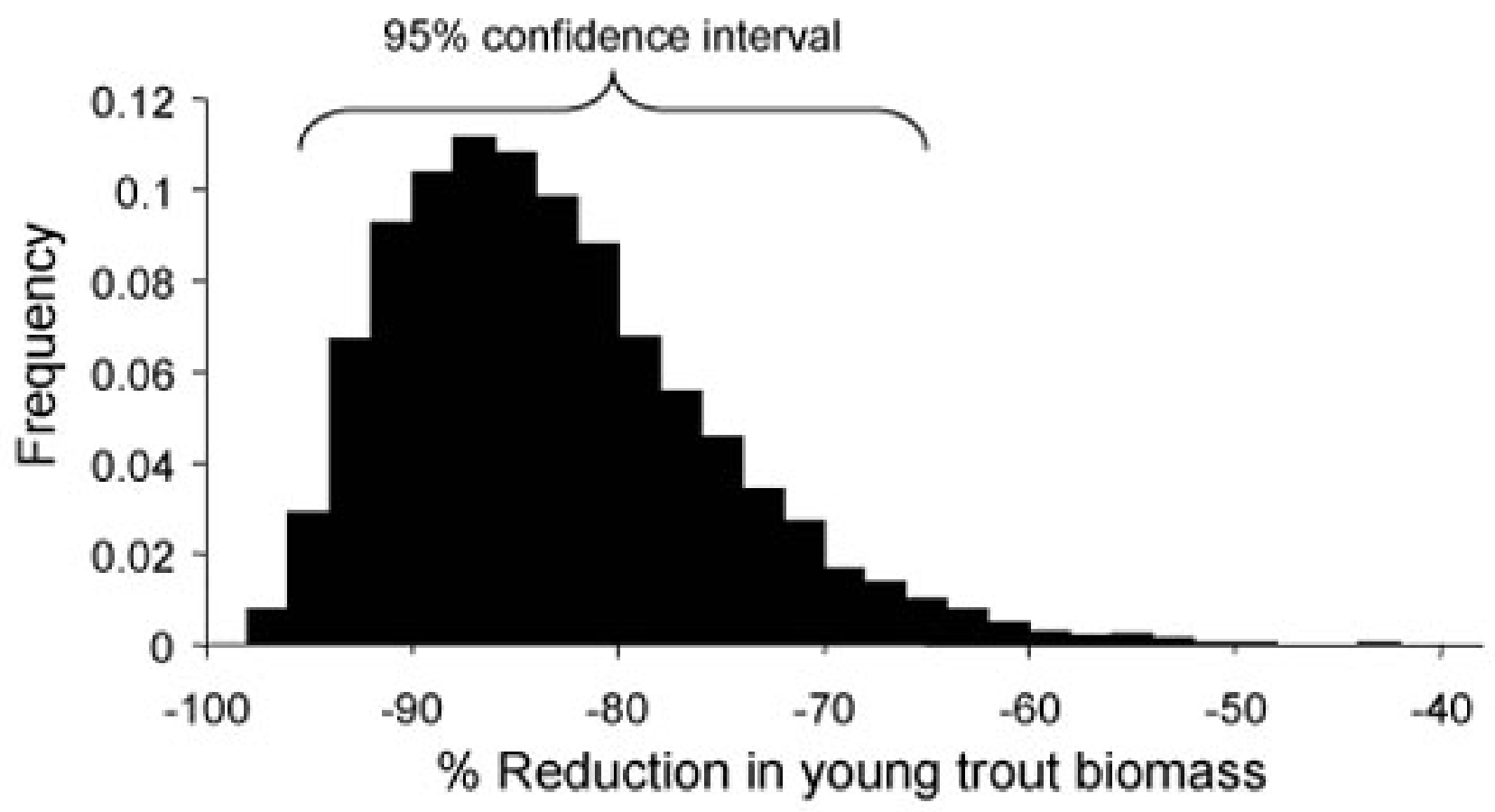

embeddedness index values at sites where young trout were observed $(\mathrm{REI}=37.7)$ and where they were not $(\mathrm{REI}=42.2)$.

The $95 \%$ confidence interval derived from the Monte Carlo assessment (Fig. 10) reveals a relatively high level of confidence in the regression predictions. Even under the best-case scenario, a $66 \%$ reduction in young trout biomass portends substantial declines in trout populations in any northern Georgia stream where vegetated riparian buffer widths are reduced to $15 \mathrm{~m}$. Under the worstcase scenario (97\% reduction), extirpation from most streams seems likely. Although other factors can influence the success of trout populations (e.g., flood regimes, water chemistry, inter-species competition, disease), this relatively narrow range of expected outcomes demonstrates that our analysis of stream temperature and sediment was adequate to produce robust results. From this, we do not conclude that other factors are unimportant. Rather, we conclude that changes in stream temperature and streambed sediment characteristics are two of the primary mechanisms of instream habitat degradation in north Georgia.

At the scale of the entire trout stream network, distributions of streams with temperatures apt to support trout reproduction are strikingly different among streams with $30-\mathrm{m}$ and $15-\mathrm{m}$ buffer widths (Table 7, Fig. 11). These distributions illustrate that riparian forests are crucial in maintaining instream temperature conducive to trout populations in north Georgia. These maps do not represent forecasts as they do not incorporate scenarios for expected future riparian conditions. However, the maps demonstrate that few streams in north Georgia could maintain trout populations if bordered by forested riparian buffers $15 \mathrm{~m}$ or less in width.

\section{Study Limitations}

Our research was successful in determining the specific question posed to us by the Georgia Legislature: streams bordered by $15-\mathrm{m}$ forested 
Table 7. Expected percentages of stream segments supporting high, marginal, and low quality thermal habitat (defined in Fig. 8) for 30- vs. 15-m average forested riparian buffer widths. The distribution of these streams across the trout stream network is shown in Fig. 11.

\begin{tabular}{lll}
\hline \hline Thermal habitat quality & 30 -m average riparian buffer width & 15 -m average riparian buffer width \\
\hline High & $18.8 \%$ & $0.7 \%$ \\
Marginal & $44.4 \%$ & $8.1 \%$ \\
Low & $36.8 \%$ & $91.2 \%$
\end{tabular}

riparian buffers are not apt to support trout populations in north Georgia. Yet, other relevant questions remain unanswered.

Our analysis was not intended to determine whether 30-m buffer widths are sufficient to protect trout populations, and we did not attempt to estimate the buffer width that would be sufficient to sustain trout populations at a particular level over time. A science-based recommendation for minimum necessary buffer widths would require additional data on trout populations (e.g., field reconnaissance of spawning redds, seasonal sampling, recruitment success) and on the relationships between aquatic habitat and buffers wider than $30 \mathrm{~m}$. Additionally, because this study characterized mean riparian buffer width, it does not address the effects of deforested gaps along riparian buffer corridors.

Separating the influence of catchment forest cover from riparian forest cover is difficult because land cover variables are commonly correlated (e.g., Richards and Host 1994, Roth et al. 1996, Stewart et al. 2001, Scott et al. 2002, Wang et al. 2003). We overcame this statistical limitation by using the spatial database for the trout stream network to select sampling sites with uncorrelated forest cover values (Fig. 7). Data from these sites show that riparian forest conditions-not catchment forest conditions - were the statistically significant driver of stream temperature at existing deforestation levels in north Georgia (Fig. 9). Yet, we cannot conclude that aquatic habitat quality is independent of land use outside the riparian zone because our study: 1) was not designed to test for wholecatchment effects; 2) did not address aspects of aquatic habitat known to be influenced by catchment conditions (e.g., flow regime, water chemistry, and catchment-scale sediment regimes); and 3) most importantly, focused on predominantly forested catchments (for additional discussion, see Jones 2004). Studies in deforested catchments (e.g., intensive agricultural and urban systems) have shown that catchment-wide land-use alterations can overwhelm the capacity of riparian buffers to support high-quality instream habitats and associated biotic communities (Roth et al. 1996, Wang et al. 2003, Roy et al. 2005). We can expect much greater levels of deforestation in north Georgia as human populations and urbanization increase substantially in the coming decades (Wear and Bolstad 1998, U.S. Census Bureau 2000, Gragson and Bolstad 2006). Therefore, protecting north Georgia's aquatic habitats and cold-water aquatic assemblages may require catchment-scale land-use planning in addition to adequate riparian buffer widths.

\section{Challenges of Conducting Ecological Assessments to Inform Legislative Decisions}

As scientists in a rapidly changing world, we are sometimes asked to determine how regulatory and political decisions will influence ecosystems and their associated goods and services. Delivering quantitative ecological assessments that are relevant to the regulatory decision-making process requires a strategic research focus and analyses that yield findings accessible to the public and politicians. By targeting specific questions facing policy makers and presenting results in a form that non-scientists 
Fig. 11. Distribution of streams by thermal habitat quality if upstream riparian buffer widths were: A) 30 $\mathrm{m}$; or B) $15 \mathrm{~m}$. Thermal habitat quality was classified from the logistic regression in Fig. 8. This figure is not intended as a scenario; all streams across north Georgia are not expected to have uniform 15-m wide buffers simultaneously. It is intended to show the approximate distribution of individual stream segments apt to maintain the temperature conditions necessary for trout populations if bordered by a 30$\mathrm{m}$ or $15-\mathrm{m}$ wide riparian buffer.

A) $30-\mathrm{m}(100-\mathrm{ft})$ riparian buffer width

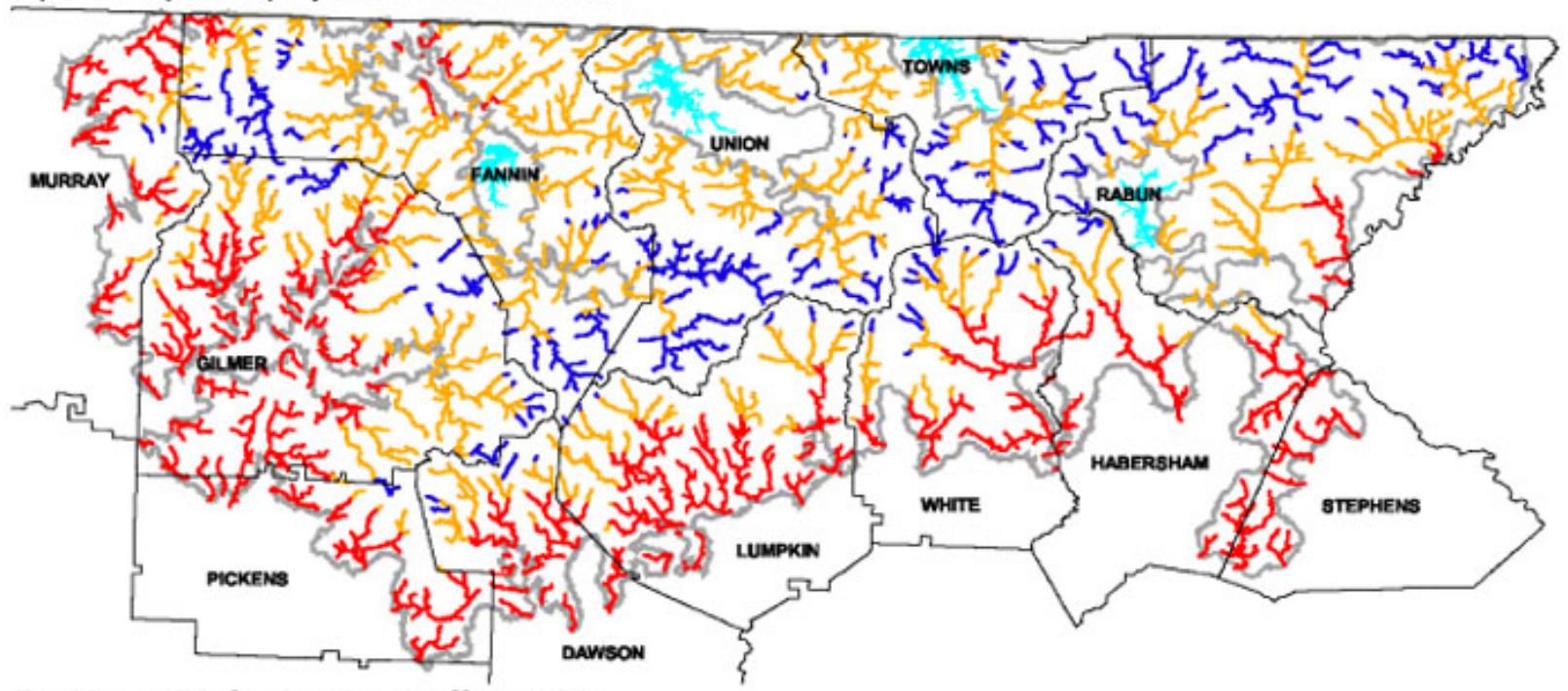

B) $15-\mathrm{m}(50-\mathrm{ft})$ riparian buffer width

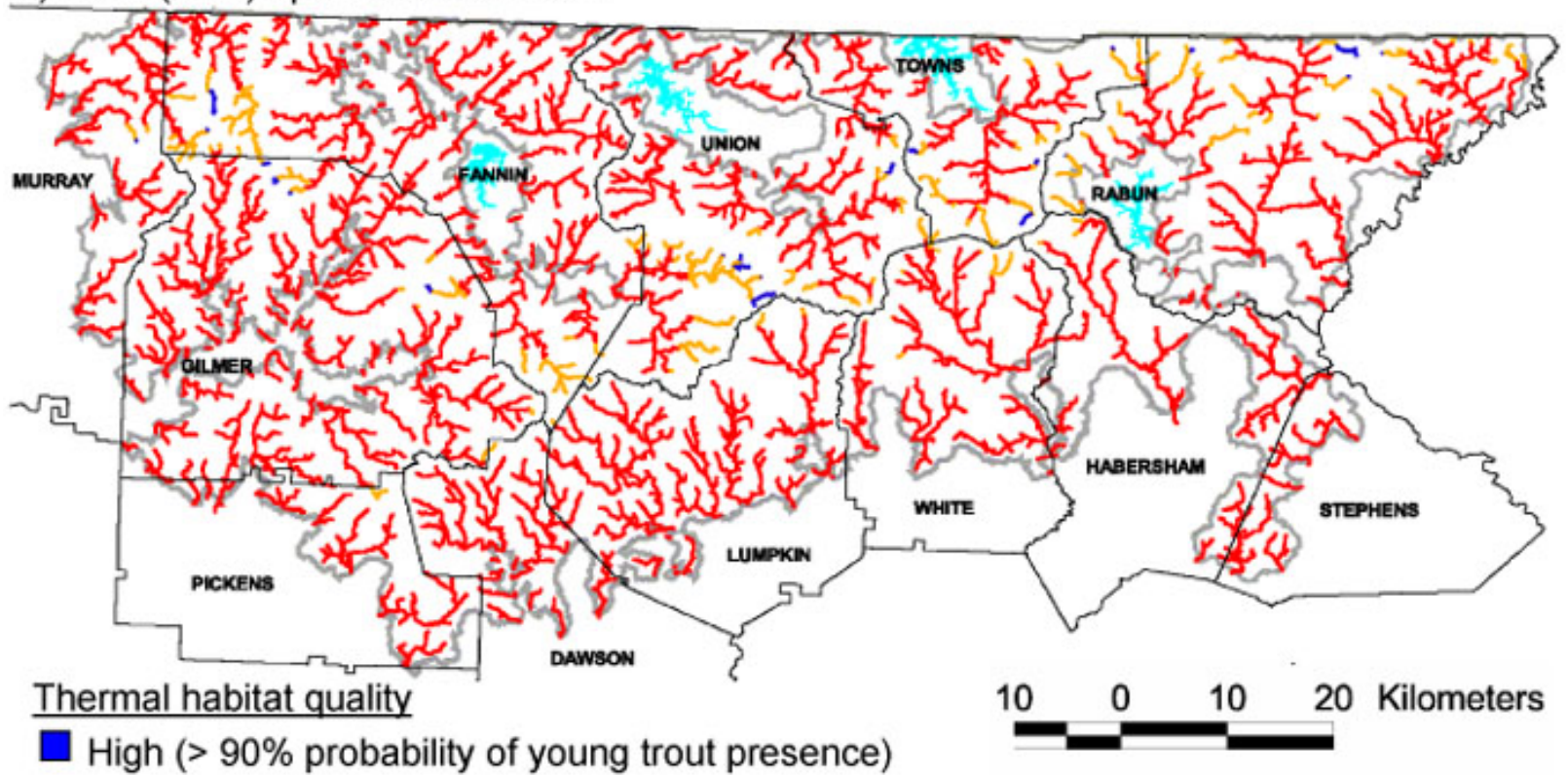

Marginal ( $90-50 \%$ probability of young trout presence)

Low (50 - $0 \%$ probability of young trout presence) 
can interpret, research will be most useful for informing sustainable development planning.

Our research required us to document changes in aquatic habitat (temperature and sediment) associated with the buffer width reduction. These changes, however, are only compelling in the political process when they are linked directly to populations or ecosystem responses to which the non-scientist can relate (e.g., trout reproductive success). Although understanding the consequences of increasing temperature and sediment may require a specialized scientific background or explanation, understanding the likely outcome of a $66 \%$ to $97 \%$ reduction in trout reproductive success does not. To make our findings more accessible to the nonscientist, we first demonstrated the non-linear relationship between stream temperature and probability of young trout presence (Fig. 8). This relationship illustrates how the modest temperature increases expected with the buffer width reduction can substantially diminish trout reproductive success, and is especially important because existing stream temperature conditions approach the thermal tolerances for rainbow and brown trout (Table 1). Second, we linked our habitat data to an environmental resource with significant economic and recreational value; annually, trout fishing generates over $\$ 172$ million in trout fishing expenditures and $\$ 10.2$ million in Georgia State and federal taxes (DeMeo et al. 2004). Third, we expanded our analysis to the landscape and provided graphical representations of our findings that help the non-scientist understand the potential for ecosystem-wide response to regulatory decisions (Fig. 11). Overall, this analysis of potential reductions in trout reproductive success at the landscape scale illustrates how scientific information can be accessible to general audiences and, therefore, better inform political decisions concerning sustainable natural resource management.

Responses to this article can be read online at: http://www.ecologyandsociety.org/voll1/iss2/art15/responses/

\section{Acknowledgments:}

Funding for this research was provided by the Georgia Environmental Protection Division. Additional support for manuscript completion was provided by Eco-metrics, Inc. Comments from Mary
Freeman, Ashley Helton, and two anonymous reviewers greatly improved the manuscript. Field and laboratory assistance from many people made this research possible. We would like to thank the following people for all their hard work: Laura England, Erin Ervin, Grant Galland, Devon Helfmeyer, Malia Helfmeyer, Steve Madritch, Austin Meadows, Gretchen Loeffler Peltier, Lane Rivenbark, Allison Roy, Mark Scott, Drew Taylor, Gretchen Turner, and Sabrina White-scarver.

\section{LITERATURE CITED}

Barton, D. R., and W. D. Taylor. 1985. Dimensions of riparian buffer strips required to maintain trout habitat in southern Ontario streams. North American Journal of Fisheries Management 5:364378.

Behnke, R. J. 2002. Trout and salmon of North America. Chanticleer Press, New York, New York, USA.

Correll, D. S. 1997. Vegetated stream riparian zones: their effects on stream nutrients, sediments, and toxic substances (an annotated and indexed bibliography). [online] URL: http://www.unl.edu/nac/ riparianbibliography.htm.

Crisp, D. T. 2000. Trout and salmon: ecology, conservation, and rehabilitation. Blackwell Sciences, Oxford, UK.

Curry, R. A., and W. S. MacNeill. 2004. Population-level responses to sediment during early life in brook trout. Journal of the North American Benthological Society 23:140-150.

Davies, P. E., and M. Nelson. 1994. Relationships between riparian buffer widths and the effects of logging on stream habitat, invertebrate community composition and fish abundance. Australian Journal of Marine and Freshwater Research 45:1289-1305.

DeMeo, T. A., D. R. Christy, and J. E. Kundell. 2004. Georgia's trout stream buffer protection evaluation under the Georgia erosion and sedimentation act and Georgia water quality control act. Carl Vinson Institute of Government, University of Georgia, Athens, GA. [online] URL: http://www.rivercenter.uga.edu/publications/pdf/ 
buffer implementation.pdf

FEMAT. 1993. A federal agency guide for pilot watershed assessment. Version 1.2. Forest Ecosystem Management Team, USDA Forest Service, Portland, Oregon, USA.

Georgia Environmental Protection Division. 2004. Rules for water quality. Chapter 391-3-6. Georgia Department of Natural Resources, Atlanta, Georgia, USA.

Goetz, S. J., R. K. Wright, A. J. Smith. E. Zinecker, and E. Schaub. 2003. IKONOS imagery for resource management: tree cover, impervious surfaces, and riparian buffer analyses in the midAtlantic region. Remote Sensing of Environment 88:195-208.

Gordon, N. D., T. A. McMahon, and B. L. Finlayson. 1992. Stream hydrology: an introduction for stream ecologists. John Wiley, West Sussex, UK.

Gragson, T. L., and P. V. Bolstad. 2006. Land use legacies and the future of southern Appalachia. Society and Natural Resources 19:175-190.

Gregory, S. V., F. J. Swanson, W. A. McKee, and K. W. Cummins. 1991. An ecosystem perspective of riparian zones: focus on links between land and water. BioScience 41:540-551.

Hausle, D. A., and D. W. Coble. 1976. Influence of sand in redds on survival and emergence of brook trout (Salvelinus fontinalis). Transactions of the American Fisheries Society 105:57-63.

Jones, E. B. D., G. S. Helfman, J. O. Harper, and P. V. Bolstad. 1999. Effects of riparian forest removal on fish assemblages in southern Appalachian streams. Conservation Biology 13:1454-1465.

Jones, K. L. 2004. Predicting trout population and fish assemblage responses to reduced riparian buffer widths in northern Georgia, USA. Thesis. University of Georgia, Athens, Georgia.

Kiffney, P. M., J. S. Richardson, and J. P Bull. 2003. Responses of periphyton and insects to experimental manipulation of riparian buffer width along forest streams. Journal of Applied Ecology 40:1060-1076.
Lee, P., C. Smyth, and S. Boutin. 2004. Quantitative review of riparian buffer width guidelines from Canada and the United States. Journal of Environmental Management 70:165180.

Marcus, M. D., M. K. Young, L. E. Noel, and B. A. Mullan. 1990. Salmonid-habitat relationships in the western United States: a review and indexed bibliography. General Technical Report RM-188. U.S. Department of Agriculture Rocky Mountain Forest and Range Experiment Station, Fort Collins, Colorado, USA.

Naiman, R. J., and H. Decamps. 1997. The ecology of interfaces: riparian zones. Annual Review of Ecology and Systematics 28:621-658.

Naiman, R. J., R. E. Bilby, and R. A. Bisson. 2000. Riparian ecology and management in the Pacific Coastal Rain Forest. BioScience 50:996-1011.

Power, G. 1980. The brook charr, Salvelinus fontinalis. Pages 141-203 in E. K. Balon, editor. Charrs-trout fishes of the genus Salvelinus. W. Junk, The Hauge, The Netherlands.

Pusey, B. J., and A. H. Arthington. 2003. Importance of the riparian zone to the conservation and management of freshwater fish: a review. Marine and Freshwater Research 54:1-16.

Richards, C., and G. E. Host. 1994. Examining land use influences on stream habitat and macroinvertebrates: a GIS approach. Water Resources Bulletin 30:729-738.

Richter, A., and S. A. Kolmes. 2005. Maximum temperature limits for chinook, coho, and chum salmon, and steelhead trout in the Pacific Northwest. Reviews in Fisheries Science 13:23-49.

Roth, N. E., J. D. Allan, and D. E. Erickson. 1996. Landscape influences on stream biotic integrity assessed at multiple spatial scales. Landscape Ecology 11:141-156.

Roy, A. H., C. L. Faust, M. C. Freeman, and J. L. Meyer. 2005. Reach-scale effects of riparian forest cover on urban stream ecosystems. Canadian Journal of Fisheries and Aquatic Sciences 62:23122329. 
Salo, E. O., and T. W. Cundy, editors. 1987. Streamside management forestry and fishery interactions. Institute of Forest Resources, University of Washington, Seattle, Washington, USA.

Schneider, J. C., P. W. Laarman, and H. Gowing. 2000. Length-weight relationships. In J. C. Schneider, editor. Manual of fisheries survey methods II: with periodic updates. Fisheries Special Report 25. Michigan Department of Natural Resources, Ann Arbor, Michigan, USA.

Scott, M. S., G. S. Helfman, M. E. McTammany, E. F. Benfield, and P. V. Bolstad. 2002. Multiscale influences on physical and chemical stream conditions across Blue Ridge landscapes. Journal of American Water Resources Association 38:1379_ 1392.

Scott, W. B., and E.J. Crossman. 1973. Freshwater fishes of Canada. Bulletin 184. Fisheries Research Board of Canada, Ottawa, Ontario, Canada.

Sokal, R. R., and F. J. Rohlf. 1995. Biometry: the principles and practice of statistics in biological research. $3^{\text {rd }}$ edition. W. H. Freeman and Company, New York, New York, USA.

Stewart, J. S., L. Wang, J. Lyons, T, J. A. Horwatich, and R. Bannerman. 2001. Influences of watershed, riparian-corridor, and reach-scale characteristics on aquatic biota in agricultural watersheds. Journal of American Water Resources Association 37:1475-1487.

Strahler, A. N. 1952. Dynamic basis of geomorphology. Geological Society of America Bulletin 63:923-938.

Suttle, K. B., M. E. Power, J. M. Levine, and C. McNeely. 2004. How fine sediment in riverbeds impairs growth and survival of juvenile salmonids. Ecological Applications 14:969-974.

Theurer, F. D., I. Lines, and T. Nelson. 1985. Interaction between riparian vegetation, water temperature, and salmonid habitat in the Tucannon River. Water Resources Bulletin 21:53-64.

United States Census Bureau. 2000. State and county quick facts for Georgia. [online] URL: http: //quickfacts.census.gov/qfd/states/13000.html.
Wallace, J. B., S. L. Eggert, J. L. Meyer, and J. R. Webster. 1997. Multiple trophic levels of a forest stream linked to terrestrial litter inputs. Science 277: 102-104.

Wang, L., J. Lyons, and P. Kanehl. 2003. Impacts of urban land cover on trout streams in Wisconsin and Minnesota. Transactions of the American Fisheries Society 132:825-839.

Waters, T. F. 1995. Sediment in streams: sources, biological effects, and control. American Fisheries Society, Bethesda, Maryland, USA.

Wear, D. N., and P. V. Bolstad. 1998. Land-use changes in the southeastern Appalachian landscapes: spatial analysis and forecast evaluation. Ecosystems 1:575-594.

Wenger, S. 1999. A review of the scientific literature on riparian buffer width, extent, and vegetation. Office of Public Service and Outreach, Institute of Ecology, University of Georgia, Athens, Georgia, USA. [online] URL: http://outreach.ecology. uga.edu/tools/buffers/lit review.pdf. 
Appendix 1. Existing forest and thermal conditions across Georgia's trout stream network Please click here to download file 'appendix1.pdf'. 
Appendix 2. Equation and coefficients for predicting trout biomass

Please click here to download file 'appendix2.pdf'. 